\title{
KORELASI KEMAMPUAN MENYIMAK DENGAN MENULIS PUISI MAHASISWA PROGRAM STUDI PENDIDIKAN BAHASA DAN SASTRA INDONESIA UMI
}

\author{
Ihramsari Akidah \\ Fakultas Sastra, Universitas Muslim Indonesia, \\ email: ihramsari.akidah@umi.ac.id
}

\begin{abstract}
The research aims to see a significant correlation between the ability to listen to poetry and the ability to write poetry for students of the Indonesian Language and Literature Study Program at the Faculty of Literature at the Muslim University of Indonesia (UMI).Research is an expose facto that is correlational, which consists of variable $X$ that is the ability to listen to poetry as an independent variable and the Y variable the ability to write poetry as the dependent variable. In this study the population and sample were Pro students gram Stuin Indonesian Language and Literature, Faculty of Letters UMI in semester 3, as well as technique used to collect this research data is observation and test. Furthermore din this study, the data collected was analyzed using descriptive statistics of product moment correlation. The results of this study show that calculations using the product moment formula reach 0.08 because to find out whether or not there is significant correlation between listening ability and writing student poetry. So, it appears that the acquisition value of 0.08 ( $r$ xy arithmetic) $<0.388$ of ( $t$ value of the product moment table) at a significant level of $95 \%$ with the number of students 27 people. So, it needs to be emphasized that the high ability to listen to student poetry, less influence on his ability to write poetry.
\end{abstract}

Keywords: Correlation, Listening to Poetry, Writing Poetry

\begin{abstract}
ABSTRAK
Pada penilitian bertujuan untuk melihat korelasi yang signifikan antara kemampuan menyimak puisi dan kemampuan menulis puisi mahasiswa Program Studi Bahasa dan Sastra Indonesia Fakultas Sastra Universitas Muslim Indonesia (UMI). Penelitian bersifat ekspost facto yang bersifat korelasional, yang terdiri dari variabel $\mathrm{X}$ yakni kemampuan menyimak puisi sebagai variabel bebas (independen) dan variabel Y kemampuan menulis puisi sebagai variabel terikat (dependen). Dalam penelitian ini yang menjadi populasi dan sampel adalah mahasiswa Program Studi Bahasa dan Sastra Indonesia Fakultas Sastra UMI pada semester 3, serta teknik yang digunakan untuk mengumpulkan data penelitian ini adalah observasi dan tes. Selanjutnya dalam penelitian
\end{abstract}


ini, data yang terkumpul dianalisis dengan menggunakan teknik statistik deskriptif korelasi product moment. Hasil penelitian ini menujukkan bahwa perhitungan dengan menggunakan rumus product moment mencapai 0,08 karena untuk mengetahui ada tidaknya korelasi yang signifikan antara kemampuan menyimak dengan menulis puisi mahasiswa. Jadi, tampak bahwa perolehan nilai $0,08\left(\mathrm{r}_{\mathrm{xy}}\right.$ hitung $)<0,388$ dari (nilai $\mathrm{t}$ tabel product moment) pada taraf signifikan 95\% dengan jumlah mahasiswa 27 orang. Sehingga, perlu dipertegas bahwa tingginya kemampuan menyimak puisi siswa, kurang berpengaruh terhadap kemampuannya dalam menulis puisi.

Kata Kunci: Korelasi, Menyimak Puisi, Menulis Puisi

\section{PENDAHULUAN}

Menyimak dan menulis merupakan dua aspek berbahasa dan sastra yang memiliki konsep yang berbeda. Menyimak merupakan kegiatan reseptif, sedangkan menulis merupakan kegiatan produktif. Namun, kedua aspek tersebut memiliki korelasi. Setelah mahasiswa menyimak pesan, diharapkan mampu diungkapkan secara lisan, lalu dibaca, dan ditulis. Jadi, keempat aspek tersebut memiliki hubungan yang signifikan.

Keterampilan menyimak sudah mulai dipelajari dan diperoleh pada saat sekolah. Keterampilan menyimak adalah keterampilan berbahasa yang paling sering digunakan dalam kehidupan sehari-hari. Sehingga, keterampilan menyimak merupakan kebutuhan vital manusia dalam kehidupannya. Hal ini senada dengan hasil penelitian Rivers (Sutari, 1997: 8) yang mengatakan kebanyakan orang dewasa menggunakan $45 \%$ waktunya untuk menyimak, 30\% untuk berbicara, $16 \%$ untuk membaca, dan hanya $9 \%$ saja untuk menulis.

Persoalan yang telah dihadapi sekarang yakni tingkat kemampuan dan keterampilan menyimak peserta didik masih rendah. Prestasi belajar khususnya aspek menyimak umumnya belum memperlihatkan hasil yang optimal. Kenyataan tersebut menunjukkan masih perlunya diadakan perbaikan yang terusmenerus terhadap mutu pengajaran bahasa dan sastra Indonesia, khususnya pada aspek keterampilan menyimak.

Dosen sebagai ujung tombak tercapainya tujuan pendidikan perlu mengetahui apa yang akan dicapai dan sejauh mana hasil belajar yang telah dicapai oleh siswa. Dosen juga perlu mengetahui kompetensi peserta didik melalui pembelajaran hal yang harus dikembangkan secara maksimal serta bagaimana penerapannya. Selain itu, dosen juga perlu memperhatikan keterkaitan materi pelajaran dengan konteks kehidupan peserta didik. Oleh 
karena itu, seorang dosen yang profesional harus mampu memilih dan menerapkan metode atau strategi yang tepat untuk meningkatkan prestasi belajar peserta didik.

Mencermati hal tersebut, pembelajaran menyimak perlu dioptimalkan karena memiliki peran dalam kehidupan manusia pada berbagai aspek. Salah satu aspek, yaitu hubungannya dengan pembelajaran, khususnya pembelajaran menyimak pembacaan puisi. Pembelajaran menyimak pembacaan puisi perlu dioptimalkan karena diyakini memiliki hubungan dengan aspek pembelajaran puisi lainnya. Peserta didik yang mampu menyimak pembacaan puisi diharapkan mampu menulis puisi.

Korelasi terjadi pada konteks lain, seperti peserta didik yang tidak mampu menulis puisi dapat dilatih dengan menempuh strategi menyimak pembacaan puisi atau tema yang sama lalu menuliskan kembali yang telah disimak. Hasil pembelajaran menulis puisi akan lebih bermakna jika diawali dengan kegiatan menyimak pembacaan puisi. Pesan yang telah disimak menjadi bahan pengetahuan dalam menciptakan puisi.

Sebagaimana hasil pembelajaran menulis puisi bahwa peserta didik mengalami kendala dan cenderung dihindari. Hal ini disebabkan oleh tidak adanya pemahaman nilai dan manfaat lainnya yang dapat diperoleh peserta didik ketika menulis puisi. Selain itu, metode yang digunakan dalam pembelajaran puisi masih kurang sehingga minat dan kompetensi peserta didik menulis puisi juga tidak memadai.

Kendala yang terkadang ditemui oleh peserta didik dalam menulis puisi antara lain, peserta didik kesulitan menemukan ide, kesulitan menentukan katakata dalam menulis puisi, kesulitan dalam memulai menulis, kesulitan mengembangkan ide menjadi puisi karena minimnya penguasaan kosakata, dan kesulitan menulis puisi karena tidak terbiasa mengemukakan perasaan, pemikiran, imajinasinya, serta kurang mampu menghubungkan antara dunia khayal dengan dunia nyata ke dalam puisi.

Keefektifan pembelajaran menulis puisi apabila peserta didik menulis puisi dengan berbagai bantuan pengetahuan dari hasil menyimak pembacaan puisi, terutama pada aspek penginderaan (yang didengar, dilihat, dirasakan, dikhayalkan oleh penyair dalam puisi yang dibaca). Melalui pembacaan tersebut, peserta didik merasa mudah mengembangkan ide-idenya ke dalam bentuk puisi karena telah dirasakan langsung isi puisi berdasarkan hasil menyimak pembacaan 
puisi.

Berdasarkan uraian tersebut, penulis termotivasi untuk melakukan penelitian tentang "Korelasi Kemampuan Menyimak Puisi dengan Menulis Puisi Mahasiswa Program Studi Pendidikan Bahasa dan Sastra Indonesia UMI”. Kegiatan ini dilakukan untuk menemukan pemahaman yang lebih ilmiah tentang korelasi kedua aspek pembelajaran puisi, yaitu menyimak dan menulis. Hal ini dinyatakan karena selama ini dianggap bahwa kemampuan peserta didik menyimak dan menulis puisi merupakan kompetensi yang lahir dari dirinya. Padahal, kompetensi peserta didik pada kedua aspek ini saling berkorelasi.

Hal lain yang menginspirasi peneliti meneliti tentang korelasi kemampuan menyimak puisi dengan kemampuan menulis puisi pada mata kuliah telaah prosa karena kompetensi menulis puisi mahasiswa belum menunjukkan hasil yang memuaskan. Ketidakpuasan hasil tersebut dapat diatasi dengan membiasakan mahasiswa menyimak pembacaan puisi yang dapat membantu saat menulis puisi.

Tujuan dari penelitian ini dilakukan selain ingin melihat apakah ada korelasi antara menyimak dengan menulis puisi, yakni untuk memberikan gambaran dan teori baru kepada dosen bahasa dan sastra Indonesia, khususnya tentang korelasi yang signifikan terhadap kemampuan menyimak puisi dengan kemampuan menulis puisi mahasiswa.

\section{METODE PENELITIAN}

Variabel yang diamati dalam penelitian ini, yakni variabel X kemampuan menyimak puisi sebagai variabel bebas (independen) dan variabel Y kemampuan menulis puisi sebagai variabel terikat (dependen). Desain Penelitian bersifat ekspost facto yang bersifat korelasional. Disebut ekspost facto karena tidak memberikan perlakuan, tetapi mengkaji atau memeriksa efek perlakuan yang terjadi secara alamiah dan sudah berlangsung. Dikatakan korelasional karena diselidiki hubungan antarvariabel.

Setiap penelitian yang dilakukan selalu berkaitan dengan populasi dan sampel. Dalam penelitian ini yang menjadi populasi dan sampel adalah mahasiswa Program Studi Pendidikan Bahasa dan Sastra Indonesia Fakultas Sastra UMI pada semester 3. Teknik yang digunakan untuk mengumpulkan data penelitian ini, yaitu observasi dan tes. Teknik observasi digunakan mendapatkan gambaran lokasi yang dijadikan sebagai lokasi penelitian. Teknik ini juga 
digunakan untuk mendapatkan informasi tentang jumlah dan karakteristik populasi penelitian. Sedangkan teknik tes, dilakukan untuk pengambilan data melalui proses tatap muka di kelas dengan memberikan soal kepada sampel. Tes dilakukan sebanyak dua kali, yaitu tes kemampuan menyimak pembacaan puisi dan tes menulis puisi.

Skor menyimak pembacaan puisi yang mungkin dicapai oleh peserta didik berada pada rentang $0-15$. Adapun menulis puisi ada 8 aspek yang dinilai, yakni (1) tema, (2) amanat, (3) pengimajian, (4) diksi, (5) kata konkret, (6) tipografi, (7) gaya bahasa, dan

(8) nada.

Selnjutnya, dalam penelitian ini data yang terkumpul dianalisis dengan menggunakan teknik statistik deskriptif korelasi product moment. Adapun langkah-langkah menganalisis datanya, yakni (1) membuat daftar skor mentah, (2) membuat distribusi frekuensi dari skor mentah, (3) membuat klasifikasi nilai kemampuan menyimak pembacaan puisi dan menulis puisi, (4) menentukan korelasi dengan menggunakan rumus korelasi Product Moment,

(5) memberikan penafsiran terhadap koefesien korelasi yang diperoleh.

\section{HASIL DAN PEMBAHASAN}

\section{Kemampuan Menyimak Puisi (X)}

Nilai kemampuan menyimak puisi pada mahasiswa dengan 27 orang, dapat diketahui kategori tingkat kemampuan menyimak puisi pada mahasiswa seperti yang tampak pada tabel berikut ini.

Tabel 1 Distribusi Kategori dan Persentase Nilai Kemampuan Menyimak Puisi

(X)

\begin{tabular}{|l|c|c|c|c|}
\hline No. & Kategori & Nilai & Frekuensi & Persentase \\
\hline 1. & Sangat tinggi & $86-100$ & 0 & 0 \\
2. & Tinggi & $70-85$ & 12 & 44,44 \\
3. & Sedang & $56-69$ & 10 & 37,04 \\
4. & Rendah & $40-55$ & 5 & 18,52 \\
5. & Sangat Rendah & $0-39$ & 0 & 0 \\
\hline
\end{tabular}

Tampak terlihat pada tabel distribusi kategori dan persentase nilai kemampuan menyimak puisi, yaitu tidak ada mahasiswa yang mempeorleh nilai 
pada kategori sangat tinggi. Selanjutnya, mahasiswa yang memperoleh nilai pada kategori tinggi berjumlah 12 orang $(44,44 \%)$; siswa yang memperoleh nilai pada kategori sedang berjumlah 10 orang $(37,04 \%)$; siswa yang memperoleh nilai pada kategori rendah berjumlah 5 orang $(18,52 \%)$; dan tidak ada siswa yang memperoleh nilai pada kategori sangat rendah. Mencermati kategori nilai tersebut dapat dinyatakan bahwa kemampuan menyimak puisi pada mahasiswa dikategorikan tinggi.

\section{Kemampuan Menulis Puisi (Y)}

Berdasarkan perolehan nilai prestasi belajar mahasiswa tersebut dapat diketahui kategori tingkat kemampuan menulis puisi pada mahasiswa seperti yang tampak pada tabel 2 berikut ini.

Tabel 2. Distribusi Kategori dan Persentase Nilai Kemampuan Menulis Puisi

(Y)

\begin{tabular}{|l|c|c|c|c|}
\hline No. & Kategori & Nilai & Frekuensi & Persentase \\
\hline 1. & Sangat tinggi & $86-100$ & 0 & 0 \\
2. & Tinggi & $70-85$ & 14 & 51,85 \\
3. & Sedang & $56-69$ & 13 & 48,15 \\
4. & Rendah & $40-55$ & 0 & 0 \\
5. & Sangat Rendah & $0-39$ & 0 & 0 \\
\hline
\end{tabular}

Dari tabel tersebut tampak distribusi kategori dan persentase nilai kemampuan menulis puisi pada mahasiswa, yaitu tidak ada mahasiswa yang memperoleh nilai pada kategori sangat tinggi. Selanjutnya, mahasiswa yang memperoleh nilai pada kategori tinggi berjumlah 14 orang $(51,85 \%)$; siswa yang memperoleh nilai pada kategori sedang berjumlah 13 orang $(48,15 \%)$; tidak ada mahasiswa yang memperoleh nilai pada kategori rendah dan kategori sangat rendah. Kategori nilai tersebut dapat dinyatakan bahwa kemampuan menulis puisi pada mahasiswa dikategorikan sedang dan tinggi.

\section{Korelasi antara Kemampuan Menyimak dengan Menulis Puisi}

Hasil analisis data kemampuan menyimak puisi (X) dan kemampuan menulis puisi pada mahasiswa (Y), dapat diketahui korelasi yang signifikan antara kemampuan menyimak dengan menulis puisi pada mahasiswa. Untuk 
menghitung besarnya hubungan tersebut, digunakan analisis statistik inferensial teknik korelasi product-moment.

Diketahui bahwa data nilai kemampuan menyimak dengan menulis puisi pada mahasiswa. Untuk mencari hubungan antara $\mathrm{X}$ dan $\mathrm{Y}$, dapat dilihat penyajian berikut ini:

Diketahui : $\quad \sum X=1777$

$$
\begin{aligned}
& \sum \mathrm{Y}=1836 \\
& \sum \mathrm{XY}=120924 \\
& \sum \mathrm{X}^{2}=119495 \\
& \sum \mathrm{Y}^{2}=125270 \\
& \left(\sum \mathrm{X}\right)^{2}=3157729 \\
& \left(\sum \mathrm{Y}\right)^{2}=3370896 \\
& \mathrm{~N}=27 \\
& \mathrm{r}_{\mathrm{xy}}=0,08
\end{aligned}
$$

Berdasarkan hasil analisis tersebut, diperoleh $r_{x y}$ hitung $=0,08$. Hasil perhitungan tersebut, dijelaskan pengujian hipotesis sebagai bukti penerimaan hipotesis.

Dalam pengujian statistik, hipotesis ini dinyatakan sebagai berikut:

$$
\mathrm{H}_{\mathrm{O}}: \text { th } \leq \text { lawan } \mathrm{H} 1: \text { th } \geq
$$

Setelah diadakan perhitungan berdasarkan hasil statistik interferensi PEARSON R (Koefisien korelasi Product Moment), diperoleh nilai $\mathrm{r}_{\mathrm{xy}}$ hitung. Kriteria penyajiannya adalah: $\mathrm{H}_{0}$ diterima apabila $\mathrm{r}_{\text {hitung }} \leq \mathrm{r}$ tabel dan $\mathrm{H}_{\mathrm{i}}$ diterima jika $r$ hitung $\geq r_{\text {tabel. }}$ Di mana d.b. $=\mathrm{N}-1=27-1=26$. Angka inilah yang dilihat dalam tabel pada taraf signifikan 95\%. Ternyata $r_{\text {hitung }}(0,08),<r$ tabel $=0,388$. Dengan demikian, tidak ada korelasi yang signifikan antara kemampuan menyimak dengan menulis puisi pada mahasiswa. Hal ini dibuktikan oleh hasil perhitungan statistik poroduct moment yang menunjukkan bahwa $\mathrm{r}$ hitung lebih

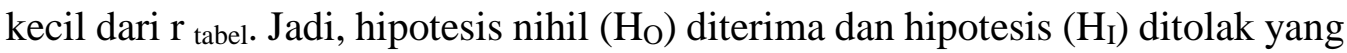
berarti (antara $\mathrm{X}$ dan $\mathrm{Y}$ ) tidak terdapat hubungan yang berarti atau meyakinkan.

Diketahui jumlah $\mathrm{N}=27$ kemudian dikonsultasikan pada tabel product moment dengan taraf signifikan 95\% diperoleh nilai 0,388 dengan taraf kepercayaan 99\%. Hal ini berarti bahwa nilai $r$ hitung sebesar 0,08 lebih kecil dari $\mathrm{r}_{\text {tabel }}$ product moment (terlampir). Hal ini menunjukkan bahwa hipotesis alternatif atau $\mathrm{H}_{\mathrm{i}}$ yang menyatakan bahwa ada korelasi yang signifikan antara kemampuan menyimak dengan menulis puisi pada mahasiswa ditolak. 
Diketahui tingkat korelasi antara kemampuan menyimak dengan menulis puisi pada mahasiswa, tingkat hubungannya dapat dinyatakan sangat rendah. Hal ini terlihat dari perolehan nilai rxy hitung sebesar 0,08 yang berada pada interval koefisien 0,00- 0,20 atau kategori korelasi sangat rendah.

Pada bagian ini di kemukakan hasil temuan yang diperoleh dalam penelitian ini. Berdasarkan pada analisis deskriptif, diketahui bahwa tidak ada korelasi yang signifikan antara kemampuan menyimak dengan menulis puisi pada mahasiswa semester 3 Prodi Pendidikan Bahasa dan Sastra Indonesia. Dalam arti bahwa semakin tinggi kemampuan menyimaki puisi, tidak berpengaruh yang signifikan terhadap kemampuan siswa dalam menulis puisi. Oleh karena itu, kemampuan menulis kurang dipengaruhi oleh kemampuan mahasiswa dalam menyimak puisi. Dengan demikian, dosen harus meningkatkan pembelajaran menyimak dan menulis puisi dan mahasiswa harus terus meningkatkan daya ingat dan menyimaknya terhadap bahan simakan sehingga hasil yang diperoleh semakin meningkat.

\section{PENUTUP}

\section{Simpulan}

Penyajian hasil analisis data dan pembahasan dapat disimpulkan bahwa kemampuan menyimak puisi pada mahasiswa semester 3 Prodi Pendidikan Bahasa dan Sastra Indonesia dikategorikan tinggi. Hal ini ditandai oleh nilai kemampuan menyimak bahan simakan rata-rata berada pada rentang nilai 70-85 (kategori tinggi), sedangkan kemampuan menulis puisi dikategorikan sedang. Hal ini ditandai oleh nilai menulis puisi yang rata-rata berada pada rentang nilai 56-69 (kategori sedang).

Selanjutnya, hasil analisis korelasi antara kemampuan menyimak degan menulis puisi sangat rendah. Artinya, semakin tinggi kemampuan menyimak puisi, kurang berpengaruh terhadap kemampuannya dalam menulis puisi.

\section{Saran}

Sesuai dengan hasil penelitian ini, diajukan saran, yakni mahasiswa hendaknya lebih meningkatkan kemampuan menyimak sastra, khususnya puisi karena kemampuan ini dapat mempengaruhi aspek pembelajaran bahasa Indonesia yang lain. 


\section{DAFTAR PUSTAKA}

Ackhadiat, Sabarti, dkk., 1994. Pembinaan Kemampuan Menulis Bahasa Indonesia. Jakarta: Erlangga.

Afaruddin, Pesu. 1990. Pengantar Apresiasi Puisi. Bandung: Angkasa.

Alwi, Hasan. 2003. Kamus Besar Bahasa Indonesia Edisi Ketiga. Jakarta: Balai Bahasa.

Aminuddin. 2002. Pengantar Apresiasi Karya Sastra. Malang : Sinar Batu Algesindo.

Arief, Ermawati. 1989. Permainan dalam Pengajaran Bahasa Indonesia. Bandung: Jurusan Pendidikan Bahasa dan Seni IKIP Bandung.

Arikunto, Suharsimi. 2006. Prosedur Penelitian: Suatu Pendekatan Praktik. Jakarta: Rineka Cipta.

Badrun, Ahmad. 1983. Pengantar I1mu Sastra. Surabaya: Usaha Nasional.

Boen, S. 1979. Apresiasi Sastra. Jakarta.

Depdiknas. 2006. KTSP Mata Pelajaran Bahasa Indonesia. Jakarta: Depdiknas.

Depoter, B. \& Hernacki, M., 2001. Quantum learning: Membiasakan Belajar Nyaman dan Menyenangkan. Terjemahan Abudurrahman Bandung: Kaifa.

Effendi, S., 1996. Bimbingan Apresiasi Puisi. Ende: Nusa Indah.

Firman. 2003. "Keterampilan Siswa Kelas II SLTPN 1 Sajoanging Kabupaten

Wajo Menulis Pengalaman Pribadi dalam Bentuk Puisi." Skripsi. Makasar: FBS UNM.

Hardiyana. 2002. Pelaksanaan Pengajaran Puisi. Skripsi. Makassar .UNM.

Harras, dkk. 1996/1997. Membaca I. Jakarta: Departemen Pendidikan dan Kebudayaan Bagian Proyek Penataran Guru SLTP setara D-III.

Hartoko, A., 1989. Pengantar Ilmu Sastra. Surabaya: Usaha Nasional.

Mirriam, Caryn. 2006. Daripada Bete Nulis Aja. Bandung: KAIFA.

Mulyasa, dkk. 1997/1998. Sanggar Sastra. Jakarta: Departemen Pendidikan dan

Kebudayaan Bagian Proyek Penataran Guru SLTP setara D-III.

Nurgiyantoro, Burhan. 2008. Penilaian Pengajaran Bahasa dan Sastra.

Yogyakarta: BPEE.

Nurhayati . 2001. Faktor Kesulitan Memahami Puisi. Skripsi . Makassar, UNM

Pradopo, Rachmat Djoko. 2002. Pengkajian Puisi. Yogyakarta: Gadjah Mada

University Press.

Semi, Atar. 1994. Kritik Sastra. Bandung: Angkasa. 
Sudjana. 1996. Metode Statistik. Bandung: Tarsito.

Suhartini. 2005. "Kemampuan Menulis Puisi Siswa Kelas III Bahasa SMA Negeri 1 Bajeng/" Skripsi. Makassar: FBS UNM.

Suhendar, dkk. 1992. MKDU Bahasa Indonesia Pengajaran dan Ujian keterampilan Menyimak dan Keterampilan Berbicara. Bandung: Pioner Jaya.

Sumardjo, J., 2001. Catatan Kecil tentang Menulis Cerpen. Yogyakarta: Pustaka Pelajar.

Sutari, Ide, K.Y., dkk. 1997. Menyimak. Jakarta: Depdikbud Bagian Proyek Penataran Guru SLTP Setara D-III.

Syafi'i. 1998. Retorika dalam Menulis. Jakarta: Depdikbud.

Tarigan, Henry Guntur. 1990. Membaca sebagai Salah Satu Keterampilan Berbahasa. Angkasa: Bandung.

Tarigan, Henry Guntur. 1990. Prinsip-prinsip Dasar Sastra. Bandung: Angkasa. Waluyo, Herman J. 1987. Teori dan Apresiasi Puisi. Jakarta: Erlangga.

Zulfahnur, dkk. 1997. Apresiasi Puisi. Jakarta: Departemen Pendidikan dan Kebudayaan. 